\title{
RESEARCH OF DEFAULT RISK LEVEL OF RUSSIAN ENERGY
}

\author{
V.G. Mokhov ${ }^{1}$, G.S. Chebotareva ${ }^{2}$ \\ ${ }^{1}$ South Ural State University, Chelyabinsk, Russian Federation \\ ${ }^{2}$ Ural Federal University, Ekaterinburg, Russian Federation \\ E-mails: mokhovvg@susu.ru,g.s.chebotareva@urfu.ru
}

The liberalization of the electricity market intensifies the competition for investors in the Russian energy market, for which the financial stability of energy companies is an important criterion. The paper presents the mathematical modelling of integrated assessment of the default risk level of Russian energy companies, taking into account their specific characteristics: type of the energy business, form of ownership, and regional specific. The research is based on the industry approach to the diagnostics of default risk level of energy companies. The approach includes the logit-model and assessment of the coefficients significance. The complexity of this model is conditioned by the study of external and internal financial and economic indicators, as well as qualitative criteria based on the introduction of dummy-variables. Four groups of default risk level of Russian energy companies are proposed. The use of mathematical modelling tools increases the accuracy of assessing the financial insolvency of energy companies in comparison with the traditional methods. Therefore, the proposed approach is novel, relevant, and practically significant. Research veracity is confirmed by the practical implementation. We recommend the use of the proposed methodology in assessment of the current state and development strategy of Russian energy companies, as well as by investors and analysts to make financial decisions.

Keywords: energy; energy business; default; probability of default; investments; risk; logit-model; modelling.

\section{Introduction}

The long period of reforming the Russian energy market led to the liberalization of the electricity market. This contributed to the development and increased competition in the Russian energy market. As a result, the problem of the energy companies to find private and, as a rule, expensive capital for current activities and for the implementation of investment programs becomes complicated. However, financial stability and level of credit risk of energy companies are important criteria in making final decisions by investors. In this regard, the problem of objective assessment and reduction of default risk level of Russian energy companies in the investment activities is very relevant and practically significant. The solution consists of two stages.

\section{Methodical Approach to Assessment of Default Risk Level of Russian Energy Sector}

The study of default risk level of Russian energy companies is based on the assessment of the forecast logit-model [1-4]:

$$
P D=\frac{1}{1+e^{Y}}
$$

where PD is Probability of Default of energy company, and is measured in specific weight according to (2): 


$$
P D=\left\{\begin{array}{l}
\text { from } 0, \text { if value of } P D \text { of energy company is minimum, } \\
\text { to } 1, \text { if value of } P D \text { is maximum; }
\end{array}\right.
$$

$e$ is the base of natural logarithm; $Y$ is an integral indicator estimated for the proposed model by formula (3):

$$
P D=b_{0}+b_{1} \cdot X_{i 1}+b_{2} \cdot X_{i 2}+\ldots+b_{n} \cdot X_{i n}
$$

where $X_{i j}$ is a value of $j$-th financial indicator for $i$-th company; $b_{j}$ is an evaluation of significance of $j$-th coefficient.

Calculation of the probability of default of Russian energy companies is based on model (4) taking into account the specific characteristics of the Russian economy and energy market [5]:

$$
Y=-a_{0}-\sum_{i=1}^{11} a_{i} K_{i},
$$

where $a_{0}, a_{1}, \ldots, a_{11}$ are industry-specific constants of significance of the coefficients (for the fuel and energy complex), and coefficients $K_{1}, K_{2}, \ldots, K_{11}$ are as follows.

The qualitative assessment of Russian energy companies is provided by coefficients $K_{1}, K_{2}, K_{7}$. Namely, $K_{1}$ takes into account the "age" factor of the energy company and takes the value in accordance with conditions (5):

$$
K_{1}=\left\{\begin{array}{l}
0, \text { if the company was created more than } 10 \text { years ago, } \\
1, \text { if the company was created less than } 10 \text { years ago. }
\end{array}\right.
$$

$K_{2}$ is a coefficient of the credit history of the energy company (6):

$$
K_{2}=\left\{\begin{array}{l}
0, \text { if company has positive credit history } \\
1, \text { if company has negative credit history }
\end{array}\right.
$$

$K_{7}$ is a coefficient of the regional affiliation of the company (7):

$$
K_{7}=\left\{\begin{array}{l}
0, \text { if the company is located in Moscow or SaintPetersburg }, \\
1, \text { if the company is located in another city. }
\end{array}\right.
$$

The quantitative assessment is based on calculation of others exogenous and endogenous financial and economic coefficients. Namely, $K_{3}$ is a coefficient of the current liquidity of the energy company; $K_{4}$ is a ratio of profit before repayment of tax and interest paid in the company for the period; $K_{5}$ is the weighted average capital of the company calculated as $K_{5}=\ln \left(\sum_{\beta=1}^{m}\left(E C_{\beta}\right)\right)$, where $E C_{\beta}$ is the equity capital of the energy company for the $\beta$-period; $K_{6}$ is the weighted average key interest rate of the Central Bank; $K_{8}=R O A$ (Return on Assets); $K_{9}=R O E$ (Return on Equity); $K_{10}$ is the growth rate of equity capital of the energy company; $K_{11}$ is the growth rate of assets of the energy company for the period. Table 1 presents the distribution of industry-specific constants taking into account the specific features of fuel and energy complex.

The proposed model allows to define conditions (2) more exactly, therefore for the probability of default of energy company we have (8):

$$
P D=\left\{\begin{array}{l}
{[0 ; 0,2), \text { if the risk of de fault is minimal, }} \\
{[0,2 ; 0,4), \text { if the risk of default is low, }} \\
{[0,4 ; 0,6), \text { if the risk of default is average, }} \\
{[0,6 ; 0,8), \text { if the risk of default is high, }} \\
{[0,8 ; 1], \text { if the risk of default is maximum. }}
\end{array}\right.
$$


The value of the constant coefficients of the model for fuel and energy complex

\begin{tabular}{|l|l|l|l|l|l|l|}
\hline Indicator & $a_{0}$ & $a_{1}$ & $a_{2}$ & $a_{3}$ & $a_{4}$ & $a_{5}$ \\
\hline Value & 30,7371 & 3,7033 & 8,9734 & $-8,6711$ & $-7,0110$ & $-1,6427$ \\
\hline Indicator & $a_{6}$ & $a_{7}$ & $a_{8}$ & $a_{9}$ & $a_{10}$ & $a_{11}$ \\
\hline Value & $-0,1399$ & $-0,6913$ & $-5,0894$ & $-15,3882$ & 7,3667 & $-22,0294$ \\
\hline
\end{tabular}

\section{Practical Assessment of Default Risk Level of Energy Companies}

We chose Russian energy companies, covering all possible types of energy business in the regions of Russia, as the objects of research. The default risk level of the energy companies was assessed for the period from 2014 to 2017. To this end we used annual reports of the energy companies. The obtained results allow to group the energy companies into four groups, depending on the dynamics of the default indicator (Tables $2-5$ ).

Table 2

Default risk level of energy companies: constant minimum value

\begin{tabular}{|c|c|c|c|c|c|c|c|c|c|}
\hline \multirow{2}{*}{ № } & \multirow{2}{*}{ Company } & \multirow{2}{*}{2014} & \multirow{2}{*}{2015} & \multirow{2}{*}{2016} & \multirow{2}{*}{2017} & \multirow{2}{*}{$\begin{array}{l}\text { Characteristic } \\
\text { of default }\end{array}$} & \multicolumn{3}{|c|}{ Conditions } \\
\hline & & & & & & & 1 & 2 & 3 \\
\hline 1 & $\begin{array}{l}\text { JSC } \\
\text { "SibGenCo" }\end{array}$ & - & $\rightarrow 0,00$ & $\rightarrow 0,00$ & $\rightarrow 0,00$ & Minimum value & 1 & 2 & 1 \\
\hline 2 & $\begin{array}{l}\text { LTD } \\
\text { "Bashkirenergo" }\end{array}$ & $\rightarrow 0,00$ & $\rightarrow 0,00$ & 0,00 & 0,00 & & 1 & 2 & 3 \\
\hline 3 & $\begin{array}{l}\text { LTD "Lukoil- } \\
\text { ES" }\end{array}$ & - & $\rightarrow 0,00$ & 0,00 & 0,00 & & 1 & 2 & 4 \\
\hline 4 & PJSC "MOEK" & - & $\rightarrow 0,00$ & $\rightarrow 0,00$ & $\rightarrow 0,00$ & & 2 & 1 & 1 \\
\hline 5 & $\begin{array}{ll}\text { JSC } & \text { "MRSK } \\
\text { Ural" } & \end{array}$ & - & $\rightarrow 0,00$ & $\rightarrow 0,00$ & $\rightarrow 0,00$ & & 2 & 2 & 3 \\
\hline 6 & PJSC "Fortum" & - & 0,10 & 0,10 & 0,10 & & 1 & 2 & 1 \\
\hline 7 & $\begin{array}{l}\text { PJSC } \\
\text { "Yakutskenergo" }\end{array}$ & - & $\rightarrow 0,00$ & 0,00 & 0,00 & & 2 & 2 & 1 \\
\hline 8 & $\begin{array}{l}\text { JSC "Concern } \\
\text { Rosenergoatom" }\end{array}$ & $\rightarrow 0,00$ & 0,00 & $\rightarrow 0,00$ & - & & 2 & 1 & 1 \\
\hline 9 & $\begin{array}{l}\text { PJSC } \\
\text { "RusHydro" }\end{array}$ & 0,00 & $\rightarrow 0,00$ & 0,00 & - & & 2 & 1 & 1 \\
\hline 10 & JSC "SO UPS" & - & 0,00 & 0,00 & $\rightarrow 0,00$ & Minimum value & 2 & 1 & 4 \\
\hline 11 & $\begin{array}{l}\text { JSC } \\
\text { "Omskenergy" }\end{array}$ & - & 0,0001 & 0,00 & 0,0015 & Slight increase & 2 & 2 & 3 \\
\hline
\end{tabular}

For further analysis, the energy companies are provided with values on three criteria in accordance with the conditions (9) - (11):

$$
\text { Form of owner ship }=\left\{\begin{array}{l}
1-\text { private capital, } \\
2-\text { preferably public capital; }
\end{array}\right.
$$




$$
\begin{aligned}
& \text { Regional specific }=\left\{\begin{array}{l}
1-\text { Moscow }, \\
2-\text { another city } ;
\end{array}\right. \\
& \text { Type of the energy business }=\left\{\begin{array}{l}
1-\text { generation, transmission, } \\
\text { distribution of energy, } \\
2-\text { trading in the market, } \\
3-\text { energy transmission, } \\
4-\text { other types. }
\end{array}\right.
\end{aligned}
$$

Table 3

\begin{tabular}{|c|c|c|c|c|c|c|c|c|c|}
\hline \multirow{2}{*}{ № } & \multirow{2}{*}{ Company } & \multirow{2}{*}{2014} & \multirow{2}{*}{2015} & \multirow{2}{*}{2016} & \multirow{2}{*}{2017} & \multirow{2}{*}{$\begin{array}{l}\text { Characteristic } \\
\text { of default }\end{array}$} & \multicolumn{3}{|c|}{ Conditions } \\
\hline & & & & & & & 1 & 2 & 3 \\
\hline 1 & JSC "KGEC" & $\overrightarrow{0,00}$ & $\overrightarrow{1,00}$ & $\overrightarrow{0,00}$ & no data & Sudden changes & 1 & 2 & 1 \\
\hline 2 & PJSC "T Plus" & 0,20 & 0,00 & 0,95 & - & & 1 & 1 & 1 \\
\hline
\end{tabular}

Default risk level of energy companies: sudden changes in the indicator

Table 4

\begin{tabular}{|c|c|c|c|c|c|c|c|c|c|}
\hline \multirow{2}{*}{ № } & \multirow{2}{*}{ Company } & \multirow{2}{*}{2014} & \multirow{2}{*}{2015} & \multirow{2}{*}{2016} & \multirow{2}{*}{2017} & \multirow{2}{*}{$\begin{array}{l}\text { Characteristic } \\
\text { of default }\end{array}$} & \multicolumn{3}{|c|}{ Conditions } \\
\hline & & & & & & & 1 & 2 & 3 \\
\hline 1 & $\begin{array}{ll}\text { JSC } & \text { "ATS } \\
\text { Energo" } & \end{array}$ & 0,00 & 0,00 & 1,00 & - & $\begin{array}{l}\text { Sudden } \\
\text { increase to }\end{array}$ & 2 & 1 & 2 \\
\hline 2 & JSC "YUTK" & 0,00 & 0,00 & 1,00 & - & $\begin{array}{l}\text { a maximum } \\
\text { value }\end{array}$ & 2 & 2 & 2 \\
\hline
\end{tabular}

Default risk level of energy companies: sudden increase to a maximum value

Table 5

\begin{tabular}{|c|c|c|c|c|c|c|c|c|c|}
\hline \multirow{2}{*}{ № } & \multirow{2}{*}{ Company } & \multirow{2}{*}{2014} & \multirow{2}{*}{2015} & \multirow{2}{*}{2016} & \multirow{2}{*}{2017} & \multirow{2}{*}{$\begin{array}{l}\text { Short } \\
\text { characteristic }\end{array}$} & \multicolumn{3}{|c|}{ Conditions } \\
\hline & & & & & & & 1 & 2 & 3 \\
\hline 1 & JSC "BashES" & 1,00 & 0,00 & 0,00 & - & Sudden & 1 & 2 & 3 \\
\hline 2 & $\begin{array}{ll}\text { Group } & \text { "Inter } \\
\text { RAO" } & \end{array}$ & - & 1,00 & 0,00 & 0,00 & $\begin{array}{l}\text { a minimum } \\
\text { value }\end{array}$ & 2 & 1 & 1 \\
\hline
\end{tabular}

Default risk level of energy companies: sudden decrease to minimum value

As a result of the assessment of default risk level, we conclude the following. First, there is not constant maximum or highest value of default of energy companies. Second, public energy companies have less level of risk than private ones. Third, the companiesorganizers of trading in the market has the greatest probability of default among all types of the energy business. Finally, we did not reveal strict relationship between regional specific and default risk level of Russian energy companies. 


\title{
Conclusions
}

1. We solved the topical problem on research of the default risk level of Russian energy companies on the basis of the industry logit-model.

2. We investigated dependence between the level of default of energy companies and their specific characteristics.

3. We recommend to use the obtained results in strategic programs for the development of Russian energy.

Acknowledgements. The work was supported by a grant of the Russian Science Foundation (project No. 17-78-10039) (Chapter 1 and 2) and by Act 211 Government of the Russian Federation, contract No. 02.A03.21.0011 (Chapter 2).

\section{References}

1. Mokhov V.G., Chebotareva G.S., Khomenko P.M. Modelling of "Green" Investments Risks. Bulletin of the South Ural State University. Series: Mathematical Modelling, Programming and Computer Software, 2018, vol. 11, no. 2, pp. 154-159. DOI: 10.14529/mmp180213

2. Sorland B.F., Rudel M.G.N. What Drives Financial Distress Risk and Default Rates of Leveraged Buyout Targets? Empirical Evidence from European Transactions, Norwegian School of Economics, 2015.

3. Varotto S.E., Silvia E., Farah H., Toledo T. Modelling Decisions of Control TransiTions and Target Speed Regulations in Full-Range Adaptive Cruise Control Based on Risk Allostasis. Theory Transportation Research Part B-Methodological, 2018, vol. 117, pp. 318-341. DOI: 10.1016/j.trb.2018.09.007

4. Minal S., Sekhar C.R., Madhu E. Development of Neuro-Fuzzy-Based Multimodal Mode Choice Model for Commuter in Delhi. Intelligent Transport Systems, 2019, vol. 13, no. 2, pp. 293-251. DOI: 10.1049 /iet-its.2018.5112

5. Khaidarshina G.A. Integrated Model to Assess the Risk of Bankruptcy. Finance, 2009, no. 2, pp. 67-69.

Received February 11, 2019

УДК 330.322.013+001.895

DOI: $10.14529 / \mathrm{mmp} 190215$

\section{ИССЛЕДОВАНИЕ ДЕФОЛТНОСТИ РОССИЙСКОЙ ЭНЕРГЕТИКИ}

\author{
В.Г. Мохов ${ }^{1}$, Г.С. Чеботарева \\ ${ }^{1}$ Южно-Уральский государственный университет, г. Челябинск, \\ Российская Федерация \\ ${ }^{2}$ Уральский федеральный университет, г. Екатеринбург, \\ Российская Федерация
}

Либерализация рынка электрической энергии активизирует борьбу за инвесторов на отечественном энергорынке, для которых важным критерием является финансовая устойчивость энергокомпаний. Статья содержит математическое моделирование комплексной оценки уровня дефолтности российских энергетических компаний с учетом их специфических характеристик: сферы энергобизнеса, формы собственности и региональной принадлежности. В основу исследования положен отраслевой подход к 
диагностике дефолтности энергокомпаний, основанный на logit-модели и оценке значимости включенных коэффициентов. Комплексность данной модели обусловлена изучением внешних и внутренних финансово-экономических показателей, а также качественных критериев на основе введения dummy-переменных. Предложены четыре группы дефолтности отечественных энергокомпаний. Использование инструментария математического моделирования повышает точность оценки финансовой несостоятельности субъектов хозяйствования в сравнении с традиционными методами, что отражает новизну, актуальность и практическую значимость предложенного подхода. Достоверность результатов исследования подтверждена практической реализацией. Разработанную методику рекомендуется использовать при оценке текущего состояния и разработке стратегии развития отечественных энергокомпаний, а также инвесторам и аналитикам в процессе принятия финансовых решений.

Ключевые слова: энергетика; энергетический бизнес; деболт; вероятность дефолта; инвестииии; риск; logit-модель; моделирование.

\section{Литература}

1. Mokhov, V.G. Modelling of «Green» Investments Risks / V.G. Mokhov, G.S. Chebotareva, P.M. Khomenko // Вестник ЮУрГУ. Серия: Математическое моделирование и программирование. - 2018. - Т. 11, № 2. - С. 154-159.

2. Sorland, B.F. What Drives Financial Distress Risk and Default Rates of Leveraged Buyout Targets? / B.F. Sorlnd, M.N. Rudel // Empirical Evidence from European Transactions, Norwegian School of Economics, 2015.

3. Varotto, S.E. Modelling Decisions of Control Transi-Tions and Target Speed Regulations in Full-Range Adaptive Cruise Control Based on Risk Allostasis / S.E. Varotto, E. Silvia, H. Farah, T. Toledo // Theory Transportation Research Part B-Methodological. - 2018. V. 117. - P. 318-341.

4. Minal, S. Development of Neuro-Fuzzy-Based Multimodal Mode Choice Model for Commuter in Delhi / S. Minal, C.R. Sekhar, E. Madhu // Intelligent Transport Systems. - 2019. - V. 13, № 2. - P. 293-251.

5. Хайдаршина, Г.А. Комплексная модель оценки риска банкротства / Г.А. Хайдаршина // Финансы. - 2009. - № 2. - С. 67-69.

Вениамин Геннадьевич Мохов, доктор экономических наук, профессор, кафедра «Математическое и компьютерное моделирование», Южно-Уральский государственный университет (г. Челябинск, Российская Федерация), mokhovvg@susu.ru.

Галина Сергеевна Чеботарева, кандидат экономических наук, доцент, кафедра «Банковский и инвестиционный менеджмент», Уральский федеральный университет (г. Екатеринбург, Российская Федерация), g.s.chebotareva@urfu.ru.

Поступила в редакиию 11 февраля 2019 г.

Вестник ЮУрГУ. Серия «Математическое моделирование

и программирование» (Вестник ЮУрГУ ММП). 2019. Т. 12, № 2. С. 166-171 